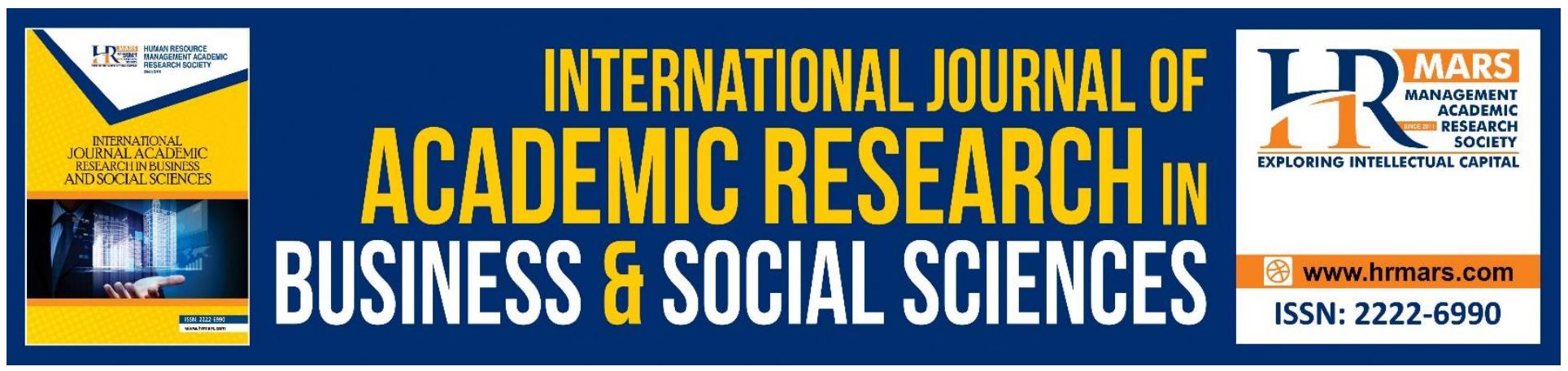

\title{
Using Teaching Effectiveness Scale as Measurement for Quality Teaching
}

Syahrina Hayati Md. Jani, Siti Asiah Md. Shahid, Mary Thomas, Peter Francis and Fatanah Jislan

To Link this Article: http://dx.doi.org/10.6007/IJARBSS/v8-i9/4704

DOI: $\quad 10.6007 /$ IJARBSS/v8-i9/4704

Received: 13 August 2018, Revised: 02 Sept 2018, Accepted: 29 Sept 2018

Published Online: 15 October 2018

In-Text Citation: (Jani, Shahid, Thomas, Francis, \& Francis, 2018)

To Cite this Article: Jani, S. H. M., Shahid, S. A. M., Thomas, M., Francis, P., \& Francis, P. (2018). Using Teaching Effectiveness Scale as Measurement for Quality Teaching. International Journal of Academic Research in Business and Social Sciences, 8(9), 1394-1404.

Copyright: (C) 2018 The Author(s)

Published by Human Resource Management Academic Research Society (www.hrmars.com)

This article is published under the Creative Commons Attribution (CC BY 4.0) license. Anyone may reproduce, distribute, translate and create derivative works of this article (for both commercial and non-commercial purposes), subject to full attribution to the original publication and authors. The full terms of this license may be seen

at: http://creativecommons.org/licences/by/4.0/legalcode

Vol. 8, No. 9, September 2018, Pg. 1394 - 1404

Full Terms \& Conditions of access and use can be found at http://hrmars.com/index.php/pages/detail/publication-ethics 


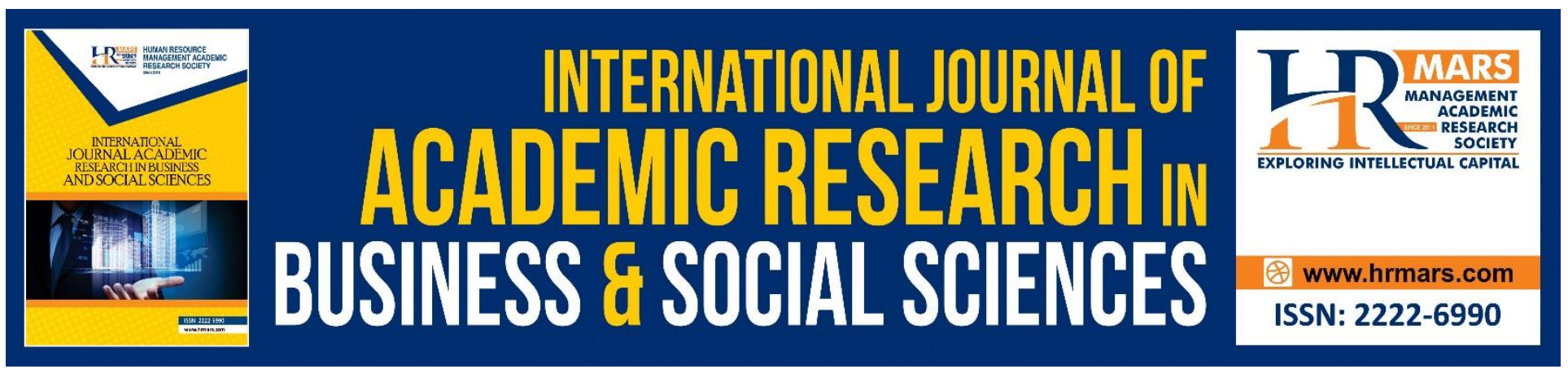

\title{
Using Teaching Effectiveness Scale as Measurement for Quality Teaching
}

\author{
Syahrina Hayati Md. Jani ${ }^{a}$, Siti Asiah Md. Shahid ${ }^{b}$, Mary Thomas ${ }^{c}$, \\ Peter Francis ${ }^{c}$ and Fatanah Jislan ${ }^{a}$ \\ ${ }^{a}$ Faculty of Business and Management, Universiti Teknologi MARA, \\ Melaka, Malaysia \\ bInstitute of Business Excellence and Faculty of Business and Management, Universiti Teknologi \\ MARA, Selangor, Malaysia \\ ${ }^{\mathrm{c} A}$ cademy of Language Studies, Universiti Teknologi MARA, Perak, Malaysia
}

\begin{abstract}
Teaching effectiveness among lecturers is an important factor to ensure high quality graduates are produced to meet the current demands of industries. Therefore, most universities in Malaysia have started to place emphasis on the quality of lecturers to produce graduates who are globally competitive. The aim of this study is to assess the reliability of teaching effectiveness components on teaching quality among lecturers. The study used a survey research design focusing on a quantitative method using survey questionnaires. A total of 275 permanent lecturers from selected universities were chosen through simple random sampling. Lecturers' teaching effectiveness was determined using the teaching effectiveness framework of Aregbeyen (2010) which comprises the components of analytical approach, clarity of teaching, lecturer-group interaction, lecturer-individual student interaction and enthusiasm of lecturer. This article demonstrates what great lecturers do to promote students' learning in class. Reliability was determined using Cronbach's alpha for internal consistency. The results of the Cronbach's alpha coefficients showed acceptable and satisfactory internal consistencies. Cronbach's alpha coefficients for analytical approach, clarity of teaching and lecturer-individual student interaction confirmed the adequacy of the internal consistencies of these scales. Although the internal consistency for lecturer-group interaction and enthusiasm of lecturer were lower in comparison to the overall five components, the results obtained can still be considered as reliable. The findings suggest that the components of the framework are valid and reliable for assessing teaching effectiveness among lecturers.
\end{abstract}

Keyword: Effective Lecturers, Effective Teaching, Quality Teaching, Teaching, Teaching Effectiveness 


\section{Introduction}

Universities in Malaysia are entrusted with the task of preparing graduates who can fulfill the demands of the country. Additionally, these institutions must also ensure a high quality of their teaching and learning process as the outcomes obtained by the learners reflect the standard of the educational institution within the country. The Vice Chancellor of Universiti Teknologi MARA (UiTM) Malaysia has voiced his concerns about quality. As quoted from his speech at the Final Presentation Session, Anugerah Kualiti Naib Canselor (AKNC), on $20^{\text {th }}$ December 2010, the Vice Chancellor said that "quality is everybody's business" (Syahrina Hayati, 2011). In the academic context, the quality of teaching is closely related to teaching effectiveness. Therefore, it is important for lecturers to acquire proper knowledge, skills and abilities to make sure they can perform effectively and efficiently.

\section{Phenomenon of Interest}

Lance (2014) argues that students learn from effective teachers. According to him an effective teacher consistently uses a variety of classroom practices that foster the intellectual, social, and emotional growth of all students, resulting in measurable growth that can be documented in meaningful ways. In addition, Habib (2017) in summarizing the literature of teaching effectiveness highlights that teachers have the capacity to shape the destiny of the country because of their immense ability to influence their pupils. This implies that the improvement efforts on the quality of teaching should be centered on teachers themselves. The Ministry of Education of Malaysia also highlights the importance of quality and teaching effectiveness of lecturers to produce graduates with knowledge, skills and abilities needed to compete in the modern labor market. Accordingly, the Ministry of Education (2013) also argues the importance of understanding and improving the dynamics of the teaching and learning process to adding staff and facilities (Malaysian Education Blueprint: 2013-2025).

This is because education is the most important aspect that helps to develop individuals and provide various opportunities for future (Peter, Mary, Siti Asiah \& Syahrina Hayati, 2015). Furthermore, the present economic scenario requires graduates to be independent in seeking for a job after they have graduated. Thus, they must be equipped and well prepared to face all challenges in the future. Hence, to acquire excellent teaching effectiveness, lecturers must learn and master the components that lead to teaching effectiveness (Syahrina Hayati, Siti Asiah, Mary \& Peter, 2015). One way to document teacher effectiveness is by using the teaching effectiveness framework proposed by Aregbeyen (2010) comprising of five components which are analytical approach, clarity of teaching, lecturer-group interaction, lecturer-individual student interaction and enthusiasm of lecturer.

Hence, there is a need to conduct this study as learning and mastering these components can promote students learning in class, produce high quality graduates, improve lecturers' level of competitive advantage, as well as ensure that lecturers stay relevant in their academic profession. The findings from this study would provide useful baseline information, which could improve on the educational practices and the training development of the lecturers specifically in understanding and 
INTERNATIONAL JOURNAL OF ACADEMIC RESEARCH IN BUSINESS AND SOCIAL SCIENCES

Vol. 8, No. 9, Sept. 2018, E-ISSN: 2222-6990 (C) 2018 HRMARS

preparing relevant teaching activities. Thus, a validated and reliable instrument is required to assess the teaching effectiveness among lecturers in Malaysia.

\section{Methods}

This study used a survey research design focusing on a quantitative method using a survey questionnaire to validate the teaching effectiveness components. One benefit of using survey questionnaire is that it is an effective data collection mechanism where the researcher knows exactly what is required and how to measure the variables of interest. The sampling frame was a group of university lecturers serving as permanent staff in the major higher learning institutions in Perak. There was a total of 1,619 university lecturers. By using simple random sampling technique, a total sample size of 275 was selected for this study.

The items of teaching effectiveness were divided into five components which comprise of analytical approach, clarity of teaching, lecturer-group interaction, lecturer-individual student interaction and enthusiasm of lecturer. The 20 items of the teaching effectiveness components were designed based on the literature; with a 5-point Likert scale. The scale ranged from 1 to 5 with $1=$ strongly disagree; 2 = disagree; 3 = not sure; 4 = agree and $5=$ strongly agree.

\section{Results}

A total 275 respondents participated in this study. Table 1 describes the demographic characteristics of the study population. Most of the respondents were from University B (36\%) as the total number of faculties in University B was the highest compared to other universities in Perak state. The result shows that the lecturers in universities were predominantly females $(52.4 \%)$ while the males were $47.6 \%$. However, this datum also indicates that the education sector is still attractive to men although there are other sectors that provide better career opportunities and development to them. 
INTERNATIONAL JOURNAL OF ACADEMIC RESEARCH IN BUSINESS AND SOCIAL SCIENCES

Vol. 8, No. 9, Sept. 2018, E-ISSN: 2222-6990 @ 2018 HRMARS

Table 1. Demographic Characteristics of Respondents

\begin{tabular}{|c|c|c|}
\hline Demographic Variables & $\begin{array}{l}\text { Frequency } \\
(n=75)\end{array}$ & Percentage \\
\hline \multicolumn{3}{|l|}{ University } \\
\hline University A & 71 & 25.8 \\
\hline University B & 99 & 36.0 \\
\hline University C & 55 & 20.0 \\
\hline University D & 50 & 18.2 \\
\hline \multicolumn{3}{|l|}{ Gender } \\
\hline Male & 131 & 47.6 \\
\hline Female & 144 & 52.4 \\
\hline \multicolumn{3}{|l|}{ Age } \\
\hline 56 and above & 13 & 4.7 \\
\hline $51-55$ & 27 & 9.8 \\
\hline $46-50$ & 43 & 15.6 \\
\hline $41-45$ & 37 & 13.5 \\
\hline $36-40$ & 34 & 12.4 \\
\hline $31-35$ & 46 & 16.7 \\
\hline 30 and below & 75 & 27.3 \\
\hline \multicolumn{3}{|l|}{ Length of Service (Years) } \\
\hline 26 and above & 12 & 4.0 \\
\hline $21-25$ & 18 & 6.5 \\
\hline $16-20$ & 13 & 4.7 \\
\hline $11-15$ & 43 & 15.6 \\
\hline $6-10$ & 69 & 25.6 \\
\hline 5 and below & 120 & 43.6 \\
\hline \multicolumn{3}{|l|}{ Level of Education } \\
\hline PhD. & 90 & 32.7 \\
\hline Masters & 163 & 59.3 \\
\hline Bachelors & 22 & 8.0 \\
\hline
\end{tabular}

Majority of the respondents were 30 years old and below (27.3\%) with less than 6 years of service (43.6\%). This shows that higher learning institutions in this study comprise mainly of the younger generation who are strong, intelligent, proactive, enthusiastic and motivated to use the larger space and opportunities to show their potential. Simply put, they are the precious change agent who can transform the universities to have a more competitive advantage. Nevertheless, these young people still need proper training and development since they are considered as new with insufficient working experience.

The highest proportion of respondents has an academic qualification at the Masters level (59.3\%). In most public and private universities in Malaysia, the minimum requirement for the position of lecturers is a Master's Degree. Since the largest number of respondents were those with 
INTERNATIONAL JOURNAL OF ACADEMIC RESEARCH IN BUSINESS AND SOCIAL SCIENCES

Vol. 8, No. 9, Sept. 2018, E-ISSN: 2222-6990 @ 2018 HRMARS

a length of service of 6 years or less, they may still lack knowledge in preparing teaching and learning activities and might also be looking for opportunities to continue their studies.

The interpretation of teaching effectiveness scores in the form of the average score was based on Best's principles introduced by Thaoprom (Syahrina Hayati, 2011). The maximum-minimum scores were divided by three ranges of low, moderate and high that is, $5-1 / 3=1.33$. As shown in Table 2 is the level of teaching effectiveness components.

Table 2. Levels of Agreement of Teaching Effectiveness

\begin{tabular}{cc}
\hline Level & Scale \\
\hline Low & $1.00-2.33$ \\
Moderate & $2.34-3.67$ \\
High & $3.68-5.00$ \\
\hline
\end{tabular}

Table 3 shows the result of mean scores and standard deviations of the five components of teaching effectiveness. The overall mean score for teaching effectiveness revealed that lecturers acquire high level of agreement in their teaching effectiveness $(M=4.29, S D=.36)$.

Table 3. Mean Scores and Standard Deviations of the Five Components of Teaching Effectiveness

\begin{tabular}{lll}
\hline Variables & $\boldsymbol{M}$ & $\boldsymbol{S D}$ \\
\hline Overall Teaching Effectiveness & & \\
Analytical Approach & 4.29 & .36 \\
Clarity of Teaching & 4.28 & .41 \\
Lecturer-Group Interaction & 4.31 & .45 \\
Lecturer-Individual Student Interaction & 4.26 & .43 \\
Enthusiasm of Lecturer & 4.36 & .47 \\
& 4.25 & .48 \\
\hline
\end{tabular}

The highest mean score is lecturer-individual student interaction $(M=4.36, S D=.47)$. This result shows that the lecturers highly agree that this characteristic of lecturers is crucial in promoting a positive relationship between lecturers and students. Moreover, a friendly and approachable nature both inside and outside the classroom will support the understanding between the lecturer and students (Peter, et. al., 2015). As mentioned by Delaney, Johnson, Johnson and Treslan (2010), students prefer lecturers who treat them with common courtesy and respect that helps them feel comfortable to approach the lecturer to ask questions. 
In addition, the result for clarity of teaching revealed that the lecturers highly agree that they should be able to convey the subject effectively to learners $(M=4.31, S D=.45)$. This is because students expect lecturers to have the capability to communicate freely about their subject area, possess a strong background in the area, elicit student interest and can respond to students' problems (Delaney, et. al., 2010). Therefore, the lecturers must be honest when they are unsure of certain content and provide students with the correct information in future classes (Mary, Peter, Siti Asiah \& Syahrina Hayati, 2015).

Then, the result for analytical approach shows that the lecturers highly agree that they must be able to synthesize facts and concepts from many fields and encourage critical thinking abilities in learners $(M=4.28, S D=.41)$. This is because students expect lecturers to know the subject better and must be able to communicate the knowledge excellently (Mary, et. al., 2015).

Next, the result for lecturer-group interaction indicates that lecturers highly agree that they should encourage active learning among students $(M=4.26, S D=.43)$. The purpose is to give the students the opportunity to express their views and share their knowledge and experiences in the classroom (Siti Asiah, Syahrina Hayati, Peter \& Mary, 2015).

Lastly, the lowest mean score based on the level of agreement is enthusiasm of lecturer $(M=$ $4.25, S D=.48$ ). This component of teaching effectiveness highlights that lecturers should be passionate about teaching as a profession as this attitude can affect student involvement in the classroom (Syahrina Hayati, 2011). By having a good sense of humour and being highly motivated, the lecturers can improve students' attention in the classroom and produce positive outcomes in learners (Peter, et. al., 2015).

Cronbach's alpha was used to determine the internal consistency of the scale. As shown in the Table 4 Cronbach's alpha coefficients ranged from .714 and .819 (analytical approach, clarity of teaching and lecturer-individual student interaction were $0.819,0.826$ and 0.815 , respectively). The overall teaching effectiveness internal consistency was .914, thus it can be concluded the reliability of these scales is highly acceptable. 
INTERNATIONAL JOURNAL OF ACADEMIC RESEARCH IN BUSINESS AND SOCIAL SCIENCES

Vol. 8, No. 9, Sept. 2018, E-ISSN: 2222-6990 @ 2018 HRMARS

Table 4. Summary of the Scale Reliability $(n=275)$

Components

Cronbach's Alpha

$\begin{array}{ll}\text { Teaching Effectiveness (Overall) } & .914\end{array}$

Analytical Approach $\quad .819$

Clarity of Teaching $\quad .826$

Lecturer-Group Interaction $\quad .714$

Lecturer-Individual Student Interaction $\quad .815$

Enthusiasm of Lecturer $\quad .776$

\section{Discussion}

Based on this paper, teaching effectiveness consists of five components namely, analytical approach, clarity of teaching, lecturer-group interaction, lecturer-individual student interaction and enthusiasm of lecturer.

The empirical results of the survey indicate that teaching effectiveness is mainly determined by the ability of the lecturer to individualize the instruction for students. This aspect of individualization is also discussed by Brown (2004) who emphasized that effective classroom management includes the teachers' ability to respond appropriately to the emotional, social, cultural and cognitive needs of the students.

Similarly, Danielson (2013) incorporates individualization by establishing a sense of respect and rapport between teacher and students. Therefore, the model of teaching effectiveness discussed in this study is practical in the Malaysian context as it resonates with the goals of the Malaysian Education Blueprint for Higher Education 2015-2025 which emphasizes on student-centred education (Ministry of Education, 2015). This component of lecturer-individual student interaction focuses on the personalization of students' learning experiences.

Teaching effectiveness has also been associated in this study with clarity of teaching and the analytical approach. Effective lecturers need to prepare and organize themselves meticulously, efficiently and be readily available for further consultation when necessary to improve effective learning (Peter, et. al., 2015). Furthermore, they are responsible to not only evaluate, guide and encourage so as to promote students involvement but also be ever willing to upgrade their knowledge and skills to equip students with the latest information. Students would be ready to accept and respect a lecturer who is truthful about not knowing the answer to a question but is willing to find the answer and bring it back to class (Delaney, et. al., 2010).

Teaching effectiveness has also been associated in this study with lecturer-group interaction and enthusiasm of lecturer. As stated by Gurney (2007), a lecturer who brings a sense of personal involvement to the classroom, shares the knowledge and experiences with the students and who is prepared to be part of the learning cycle, will set up a relationship which will encourage a good 
INTERNATIONAL JOURNAL OF ACADEMIC RESEARCH IN BUSINESS AND SOCIAL SCIENCES Vol. 8, No. 9, Sept. 2018, E-ISSN: 2222-6990 @ 2018 HRMARS

learning atmosphere. Other than that, the lecturer-group interaction can be enhanced by encouraging the students to apply concepts to demonstrate their understanding and by conducting class discussions.

Moreover, it is vital for lecturers to provide a student conducive classroom where they are empowered to be autonomous in their learning (Gurney, 2007). The conducive classroom is a classroom where the students can discover and experiment in a climate that recognizes the process of learning as the measure of success. Finally, the enthusiasm shown in lecturers is the motivating factor that propels learners to produce achievable results in them (Aregbeyen, 2010). Students expect the lecturer to be energetic, have an interesting style of presentation, have a sense of humour and vary the speed and tone of his or her voice.

The implication of this finding is that there is a need for lecturers to be eclectic in their approaches so as to be effective lecturers. Therefore, lecturers need to constantly reflect on their teaching styles. Using the teaching effectiveness scale as a tool will enable instructors to identify their strengths as well as weaknesses and consider appropriate strategies to improve instruction where necessary.

\section{Conclusion}

This study is an attempt to validate the psychometric properties of teaching effectiveness components on the study of teaching effectiveness among lecturers in Perak state. There are five components of teaching effectiveness that includes analytical approach, clarity of teaching, lecturergroup interaction, lecturer-individual student interaction and enthusiasm of lecturer. The selected scales in teaching effectiveness revealed that it has acceptable and satisfactory internal consistencies. This study demonstrated that the five components of teaching effectiveness were reliable and valid for assessing the teaching effectiveness among lecturers in Perak state, Malaysia.

All the five components are found to be evenly significant to enhance teaching and learning to achieve the objectives set in the curriculum. However, based on the major findings, lecturerindividual student interaction and clarity of teaching are considered the more crucial attributes required by effective lecturers. It can be concluded then that individualizing instruction is imperative for effective and efficient learning. Lecturers must ensure that instructional content, technology and pace of learning are suited to the ability and interest of each learner. The other important ingredient of teaching effectiveness is clarity of teaching. Lecturers themselves must be clear of their expectations in terms of students' understanding as well as their demonstration of that understanding through measurable actions. Students too must be equally clear of their ultimate goal of learning and how to prove that they have successfully achieved their learning goals.

To summarize, lecturers have to constantly review their teaching effectiveness by focusing on these five aspects of the teaching effectiveness framework as discussed in this study. They have to be passionate about their profession and make genuine efforts to rectify the aspects that they are lacking in so as to improve their quality of instruction. 
INTERNATIONAL JOURNAL OF ACADEMIC RESEARCH IN BUSINESS AND SOCIAL SCIENCES

Vol. 8, No. 9, Sept. 2018, E-ISSN: 2222-6990 (C) 2018 HRMARS

\section{Acknowledgment}

The authors would like to acknowledge and express gratitude to KPERAK Implementation and Coordination Corporation, Malaysia for the research grant (RD0002) awarded to the researchers for carrying out the research project; many thanks to Universiti Teknologi MARA (Perak) for approving the research project; greatest appreciation to all lecturers involved and all parties who have directly or indirectly helped in the successful completion of this study.

\section{Corresponding Author}

Syahrina Hayati Md. Jani, Universiti Teknologi MARA, Melaka Branch, Alor Gajah Kampus, Malaysia, syahr520@uitm.edu.my, Universiti Teknologi MARA, Melaka Branch, Alor Gajah Campus, KM26 Jalan Lendu, 78000 Alor Gajah, Melaka.

\section{References}

Aregbeyen, O. (2010). Students' perceptions of effective teaching and effective lecturer characteristics at the University of Ibadan, Nigeria. Pakistan Journal of Social Sciences, 7 (2), 62-69.

Brown, G. T. L. (2004). Teachers' Conceptions of Assessment: Implications for policy and professional development. Assessment in Education, 11 (3).

Delaney, J., Johnson, A., Johnson, T. and Treslan, D. (2010). Students' Perceptions of Effective Teaching in Higher Education. Memorial University of Newfoundland, Distance Education and Learning Technologies.

Gurney, P. (2007). Five factors of effective teaching. New Zealand Journal of Teachers' Work, 4 (2), 89-98.

Habib, H. (2017). A study of teacher effectiveness and its importance. National Journal of Multidisciplinary Research and Development, 2(3), 530-532.

Mary, T., Peter, F., Siti Asiah, M. S. and Syahrina Hayati, M. J., (2015). The Need for Emotional Intelligence Skills among Knowledge Workers at the Tertiary Level. International Journal of Social Science and Humanity, 5 (4), 347-351.

Nielsen, Lance D. (2014). Teacher Evaluation: Archiving Teaching Effectiveness. Music Educators Journal, 00274321, 101 (1).

Peter, F., Mary, T., Siti Asiah, M. S. and Syahrina Hayati, M. J. (2015). Importance of Teaching Effectiveness Among Lecturers in Institutes of Higher Learning in Malaysia. International Journal of Social Science and Humanity, 5 (4), 374-377. 
INTERNATIONAL JOURNAL OF ACADEMIC RESEARCH IN BUSINESS AND SOCIAL SCIENCES

Vol. 8, No. 9, Sept. 2018, E-ISSN: 2222-6990 (C) 2018 HRMARS

Siti Asiah, M. S., Syahrina Hayati, M. J., Mary, T. and Peter, F. (2015). The Relationship between Emotional Intelligence and Teaching Effectiveness among Lecturers in Public and Private Universities in Malaysia. International Journal of Social Science and Humanity, 5 (4), 408-412.

Syahrina Hayati, M. J., Siti Asiah, M. S., Mary, T. and Peter, F. (2015). The Predictors of Lecturers' Teaching Effectiveness for Public and Private Universities in Malaysia. International Journal of Social Science and Humanity, 5 (4), 384-388.

Danielson, C. (2013). The Framework for Teacher Evaluation Instrument. Princeton, NJ: The Danielson Group.

Ministry of Education. (2013). Malaysia Education Blueprint 2013-2025 (Preschool to Post Secondary Education), Ministry of Education Malaysia, Putrajaya, 2013. ISBN 978-983-344454-0.

Ministry of Education. (2015). Malaysian Education Blueprint 2015-2025 (Higher Education), Ministry of Education Malaysia, Putrajaya, 2015.

Syahrina Hayati, M. J. (2011). The relationship between emotional intelligence and teaching effectiveness among lecturers at Universiti Teknologi MARA, Puncak Alam, Selangor. Master Thesis, Universiti Teknologi MARA, Shah Alam, Selangor. 